Europe's Journal of Psychology 1/2010, pp. 102-126

www.ejop.org

\title{
Mentoring and work attitudes among nurses: the moderator roles of gender and social support
}

\author{
Dr. Samuel O. Salami \\ Department of Guidance and Counselling \\ Kampala International University
}

\begin{abstract}
This study examined the relationships of mentoring and satisfaction with mentoring with work attitudes of nurses and the moderating roles of gender and social support in the relationships. Questionnaires were used to collect data on mentoring, satisfaction with mentoring, social support (from friends, family, professional association members, co-workers and supervisors) work attitudes, (job involvement, job satisfaction, organizational commitment) and demographic factors from 470 nurses (males $=230$, females $=240$ ) from five states in Southwestern Nigeria. Data analysis included regressing work attitudes on mentoring, satisfaction with mentoring, social support and gender. Results revealed that mentoring, satisfaction with mentoring and social support predicted work attitudes and social support moderated the relationships but gender did not. The relationships were stronger for nurses who scored high on social support than for nurses who scored low on social support. The implication of the findings is that mentoring programmes should be developed by counselling and personnel psychologists for work organizations and these should be complemented with social support from family members, friends, and co-workers, professional association members and supervisors to improve the nurses' work attitudes.
\end{abstract}

Keywords: Mentoring, job involvement, job satisfaction, organizational commitment, nurses, Nigeria. 
Introduction

Several researchers have investigated the characteristics of the work group and organization, the protégé and the protégé/mentor dyad that affect psychosocial mentoring among health-care professionals (Allen \& Finkelstein, 2003; Koberg et al., 1998; Salami, 2008a). However, few studies have examined the effects of mentoring on work attitudes of nurses. With increased professional stressors such as failing economy, corporate re-engineering, right-sizing /downsizing, retrenchments, increased caseloads, managed care, and subsequent burnout, nurses are likely to feel more overwhelmed and less secure in the workplace. Empirical evidence showed that there is a lack of job satisfaction, work motivation, and organizational commitment, high incidence of job stress and turnover among nurses in general and Nigeria in particular (Adeyemo, 2006; Chang, Hancock; Johnson, Daly \& Jackson, 2005; Salami, 2002; Salami \& Olomitutu, 2002). Several strategies have been considered to combat these stressors such as formal mentoring programmes that have had particular success in other professions (Bedini, 2003; Thomas \& Lankau, 2009).

A range of benefits of mentoring for the mentor, mentee and the organization have been identified by researchers (Bedini, 2003; Greene \& Puetzer, 2002; Kilcher \& Sketris, 2003). Mentors' benefits include enhanced self-fulfillment, increased job satisfaction and feeling of value, satisfaction from sharing of their knowledge, and experience and from having a trainee succeed and eventually become a colleague; increased learning, personal growth, and leadership skills. The mentees' benefits of mentoring include increased competence, increased confidence and a sense of security, decreased stress, expanded networks (Galbraith \& MaslinOstrowski, 2000), leadership development and insight in times of uncertainty. Other benefits are increased job satisfaction, elevated promotions and pay (Allen, Eby, Poteet, Lentz \& Lima, 2004; Tenenbaum, Crosby\& Gliner, 2001), organizational commitment, and organizational citizenship behaviour (Bedini, 2003; Huang, 2004). The organisation's benefits include improved quality of work, improved productivity, increased ability to recruit, decreased attrition, increased commitment to the organization and development of partnership and leaders.

However, some negative mentoring experiences have been identified. These include: difficulties of diversified mentoring relationships when the mentor and the protégé have different values or attitudes (Eby, McManus, Simon \& Rusell, 2000), unrealistic expectations about the mentors' power to affect outcomes within an organization and mismatched expectations when the mentor and the protégé come from different backgrounds (Tenenbaum, Crosby \& Gliner, 2001). Although 
mentoring has received considerable research attention in U.S.A and Europe, it is not so in developing countries (Salami, 2008a). The findings of most research on mentoring conducted in western societies may not be directly applied to developing countries because of their different economic and socio-cultural considerations. One would expect different effects of mentoring on work attitudes in developing countries because some financial constraints and social - cultural factors would pose challenges to the viability of using one- on-one mentoring models to support the workers.

Employers may not sponsor formal mentoring programmes in their workplace due to financial constraints, retrenchment and general unemployment in the society. Individual workers may have to engage in informal mentoring activites and seek social support from family, friends, co-workers, professional association members and supervisors in their workplace. For example, the high unemployment rate in Nigeria which stood at 11.0\% in 2007 (National Bureau of Statistics, 2007) could affect the attitudes of employees and employers to mentoring (Salami, 2008a). Figures for 2008 and 2009 may not be markedly different. Considering socio-cultural perspectives, most Nigerians may not want to disclose personal, social and career development problems to people outside the family circles for fear of stigmatization or victimization (Salami, 1998, 2008b). To do that may be seen as a sign of weakness (Salami, 1998). Instead, most Nigerians would prefer relying on extended family members and friends' social support to solve their social, career and personal problems.

The Nigerian society is more collectivistic than individualistic and as such the workers are likely to seek more social support from family and friends on issues of personal, social and career importance. They may seek support from significant others such as respected co-workers, professional association members and supervisors on matters having to do with career development (Salami, 2008b). The fact that there are financial constraints is high unemployment and jobs are difficult to get, has an influence on workers behaviours. Those who are employed will want to remain on their jobs and as such they will seek social support from family members, friends and significant others when it comes to personal, social and career problems. The social support from multiple sources is likely to influence mentoring positively (a supportive relationship) to influence work attitudes of workers.

Also masculinity is highly emphasized in the society and the workplace in Nigeria than femininity. Lower numbers of women are educated and also participate in labour force and occupy higher status positions than men. There is occupational stereotyping (Salami 2008b) and gender-role stereotyping (Salami, 1998). When it 
comes to mentoring men and women are likely to have different mentoring experiences in same-gender and cross-gender mentoring. Therefore, gender may likely influence mentoring experiences which will in turn have impact on work attitudes of Nigerian workers. The purpose of this study was to investigate the relationships among mentoring, mentees' satisfaction and work attitudes and the extent to which gender and social support moderate the links.

\section{Overview of Literature}

Mentoring

Galbraith (2001) defined mentoring as a process by which persons of superior rank, special achievements, and prestige instruct, counsel, guide and facilitate the intellectual and/or career development of persons identified as protégés. There are two types of mentoring relationships - formal and informal. Informal relationships develop by mutual identification whereby mentors choose protégés whom they view as younger versions of themselves and protégés select mentors whom they view as role models (Ragins, Cotton \& Miller, 2000). Informal mentoring relationship usually focused on protégés' long-term career goals and are voluntary, unstructured and often sparked by mutual attraction and often last between three to six years (Kram, 1985).

Formal mentoring relationships usually develop through the assignment of members to the relationship by the work organization (Ragins et al., 2000). Formal mentoring relationships often last between six months and one year, and the mode, frequency and location of contact may be sporadic or specified in a relationship contract signed by both parties (Ragins et al., 2000). Formal mentors are often contracted to focus on protégés' short-term career goals. In this study, informal mentoring was investigated because there are no formal mentoring programmes for nurses in Nigeria (Salami, 2008a). Since there is paucity of research on mentoring and work attitudes and non-existence of formal mentoring but existence of informal mentoring in most work organizations in Nigeria (Salami, 2008a), an investigation of this type among nurses is warranted.

Mentoring and work attitudes

Job satisfaction is defined as the positive emotional response to a job situation resulting from attaining what the employee wants and values from the job. Mentoring has been found to be significantly related to job satisfaction by researchers (Caine, 2008; Bedini, 2003; Scandura \& Williams, 2004; Wasserstein, 
Quistberg \& Shea, 2007). However, Ecklind (1998) did not find significant correlation between mentoring and job satisfaction among critical care nurses.

Organizational commitment is defined as the individual's attachment to and identification with the employing organisation's goals and values (Mowday, Steers \& Porter, 1979). Some studies have found significant relationship between formal or informal mentoring and organizational commitment or intention to leave the organization (Lankau \& Scandura, 2002; Ragins, Cotton \& Miller, 2000; Scandura \& Williams, 2004; Thomas \& Lankau, 2009). However, Lovis, Posner and Powell (1983) found no significant relationship between being mentored and intention to stay with the organization.

Job involvement is the degree to which an individual is involved in a particular job and actively participates in it. Job involvement depends on the degree to which the job is perceived to meet one's salient needs be they intrinsic or extrinsic. Koberg, Boss and Goodman (1998) found that mentoring was a significant predictor of job involvement among hospital nurses.

Satisfaction with mentoring experience and work attitudes

Mentoring experiences fall along a continuum ranging from highly satisfying, marginally satisfying to dissatisfying or dysfunctional or harmful at the extreme (Eby, McCanus, Simon \& Russell, 2000; Ragins et al., 2000). Chao, Walz and Gardner (1992) and Ragins et al., (2000) found that protégés who reported highly satisfying informal or formal mentoring experience demonstrated greater job satisfaction, organizational commitment and satisfaction with opportunities for promotion.

Direct and moderator effects of social support

Social support is the extent to which individuals feel that provisions of social relationships are available to them. The social relationships may be in the form of provision of emotional, informational or tangible (material) support from family members, supervisors, peers/coworkers, subordinates and friends outside of work (Allen \& Finkelstein, 2003). Empirical studies indicated that social support was positively correlated with work attitudes (Allen \& Finkelstein, 2003; Higgins \& Thomas, 2001; Kram, 1985). It is expected that the higher the social support the higher the work-related outcomes.

In addition to the direct effect of social support on work attitudes, it is possible that it interacts with mentoring relationships to influence work attitudes. For instance, effective use of social support resources can pave the way for effective mentoring relationships. Some empirical studies support this type of moderating relationships. 
For example, some researchers examined the effects of mentoring relationship combined with other supportive relationships and concluded that it is the composition of one's entire constellation of developers that accounts for the better career outcomes (job performance) (Higgins \& Thomas,2001; Seibert, Kraimer, \& Liden, 2001; Van Emmerik, 2004, 2008). The underlying mechanism may be that mentoring especially flourishes under favourable team or multiple support conditions. In this study, the multiple social support comprises support from family, friends and significant others (co-workers, professional associations members, and supervisors). The logic underlying the selection of social support as a moderator of the mentoring - work attitudes relationship is based on some socio- cultural factors. The Nigerian society is more collectivistic than individualistic as such it is appropriate for a worker to seek social support from family, friends and significant others on some personal, social and career issues (Salami, 2008b). The support from family and friends will take care of social and personal problems while that from significant others will likely take care of the career development problems of the workers.

Also because the Nigerian society is cautious about disclosing personal, social and career information to people outside the family, it is usual for workers to seek social support from family members and friends on matters of personal, social and even career concerns. Even when the workers want to make use of mentors, they will have to consult with family members and friends for approval first (Salami, 2008a). The combined social support from these multiple sources will likely reinforce whatever mentoring relationship the workers might have in influencing their work attitudes. Therefore, it was expected that the relationship between mentoring or satisfaction with mentoring and work attitudes will be stronger for participants with high social support than those with lower social support.

The current financial constraints, high unemployment rate and workplace staff shortages may challenge the use of one-on-one mentoring models for workers in Nigeria. These may have some influence on the behaviours and attitudes of the workers and the employers towards mentoring. Those who are employed will want to remain on their jobs and as such they will seek social support from family, friends and significant others on matters dealing with personal, social and career development problems. Due to financial constraints, employers may not sponsor formal mentoring programmes. Individual may have to rely on informal mentoring and social support from family members, friends and significant others, such as co-workers, professional association members and supervisors. Social support from multiple sources are likely to influence positively any mentoring relationships the workers have, which will in turn influence their work attitudes positively. 
To the knowledge of the present author, no study has examined the moderator role of social support in the relationship between mentoring or satisfaction with mentoring and work attitudes. Social support is also expected to serve as a buffer against the exacerbation of response to stress from marginally satisfying or unsatisfying dysfunctional harmful mentoring experience. It is proposed that social support will moderate the relationships between level of mentoring or satisfaction with mentoring and work attitudes. Therefore, for nurses scoring high on social support, the relationships between mentoring and work attitudes will be stronger than for nurses scoring low on social support.

\section{Direct and moderator effects of gender}

Empirical evidence has shown that gender has significant correlation with job satisfaction and organisational commitment (Carmeli, 2003) but not job involvement. On the moderating effects of gender on the relationship between mentoring or satisfaction with mentoring and work attitudes, some researchers found that gender moderated the relationship between mentoring and work attitudes (Scandura \& Williams, 2001), others did not (Ragins et al., 2000). The logic behind selecting gender as a moderator of the mentoring- work attitudes relationship is based on some sociocultural factors. In the Nigerian society, more emphasis is placed on masculinity than femininity. There are lower numbers of women who receive education, participate in labour force and occupy senior positions than men. There is also occupational stereotyping (Salami, 2008b) and gender-role stereotyping (Salami, 1998). As regards mentoring, empirical evidence showed that differences exist between the mentoring experiences of males and females especially from same-gender and cross-gender mentoring (Chandler \& Kram, 2010; Fowler, Gudmundsson \& O'Gorman, 2007). Same-gender mentoring has fewer problems compared with cross-gender mentoring (e.g. female protégé and male- mentor pair) which is fraught with more difficulties such as fear of sexual harassment, unproductive closeness, different expectations or miscommunication due to gender perception (Chandler \& Kram,2010).

Also some individual and organizational factors may inhibit the prospering of mentoring relationships for women (Kalmer \& Rasheed, 2006). For example, women's career patterns often have interruptions and few advancement opportunities resulting from discrimination and segregation all of which impair the establishment of mentoring relationship. Career interruptions related to family or care taking roles impede the formation of mentoring relationships according to traditional mentoring model. Women may therefore, not expect much benefit from mentoring relationship compared with men. Furthermore, women often divide, their time between work and family compared with men who devote more time to their 
professional lives. In Nigeria, the society expects the women to take care of the home (children, the aged, and the husband) and to lay less emphasis on their careers. In contrast, the men are expected to be breadwinners of their families and as such they need to lay more emphasis on their careers (Salami, 2007). On average, studies in organizations show that women have more extensive networks of social support than men, but that men's networks include more high-status, influential individuals (van Emmerik, Baugh \& Euwema;2005). As a result, men are more likely to receive career benefits from network of social support than are women. In Nigeria, the society frowns at women engaging in certain relationships such as cross-gender mentoring. Therefore, men are likely to be more motivated than women to establish mentoring relationship that will help improve their work outcomes.

Some circumstances in the mentoring process limit the formation of mentoring relationship among women (Dreher \& Cox, 1996; Fowler, Gudmundsson \& O'Gorman, 2007). For example, there is a greater likelihood in cross-gender mentoring relationships for anxiety to develop regarding intimacy and physical attraction. Also, in addition to the prospect of actual intimacy and romantic involvement, there is potential for public-image problems associated with crossgender mentoring. Relationships that do not involve romantic attachment may be perceived as such by others, thus leading to negative consequences for both mentor and protégé (Dreher \& Cox, 1996). Furthermore, because of gender-role stereotypes, men may underreport their mentoring relationship and functions provided by their mentors to maintain self-perception and social perception of career independence and status. On the basis of the factors discussed, one may expect that gender may moderate the relationship between mentoring and work attitudes. Given that individual, socio-cultural and organizational factors and crossgender difficulties inhibit the prospering of mentoring relationship for women, it is likely that the relationship between mentoring and work attitudes will be stronger for men than for women.

\section{Statement of the problem}

Given the paucity of empirical studies relating mentoring to work attitudes of healthcare professionals and the inconsistencies in some empirical findings on the link between mentoring and work attitudes, there is need to examine the relationship between mentoring and work attitudes of nurses. Against this background, this study assessed the relationships among mentoring, expressed mentees' satisfaction and work attitudes of the nurses. The study further examined the extent to which social support and gender moderate the ascertained relationship. Information to be derived from the findings of this study will help counselling and organizational 
psychologists in developing mentoring programmes designed to assist the nurses in developing appropriate work attitudes.

Hypotheses

Based on the reviewed literature, the following hypotheses were tested:

$\mathrm{H}_{1}$ - Gender will significantly predict work attitudes.

$\mathrm{H}_{2}$ - Mentoring will significantly predict work attitudes.

$\mathrm{H}_{3}$ - Satisfaction with mentoring experience will significantly predict work attitudes.

$\mathrm{H}_{4}$ - Social support will significantly predict work attitudes.

$\mathrm{H}_{5}$ - Social support will moderate the relationship between mentoring and work attitudes; and between satisfaction with mentoring and work attitudes, such that for nurses scoring high on social support, the relationships between mentoring, satisfaction with mentoring and work attitudes will be stronger than for nurses scoring low on social support.

$\mathrm{H}_{6}$ - Gender will moderate the relationship between mentoring and work attitudes and between satisfaction with mentoring and work attitudes, such that for male nurses, the relationships between mentoring, satisfaction with mentoring and work attitude will be stronger than for female nurses.

Methods

\section{Research Design}

This study adopted a survey research design in which questionnaires were used to collect data from the respondents in examining the relationship between mentoring, satisfaction with mentoring, social support and work attitudes.

\section{Participants}

Four hundred and seventy nurses (males $=230,48.94 \%$, females $=240,51.06 \%$ ) randomly selected from twenty five public hospitals from five states in southwest Nigeria participated in this study. These hospitals were chosen because they had similar conditions of service, facilities, equipment and personnel. One hundred nurses were randomly selected from each of the five states involved in this study. Twenty nurses were selected from each hospital by simple random sampling using dip hand into hat method. Of the 500 questionnaires distributed, 30 were not properly filled and were discarded and were not used for the data analysis. Four hundred and seventy were thus used for analysis. The nurses' ages ranged from 21 to 
54 years with a mean age of 36.56 years (S.D. $=7.80$ ). The participants had required professional nursing and midwifery certificates for practising as recognized by the Nursing and Midwifery Council in Nigeria. The participants' working experience ranged from 2 to 25 years. Their job ranks ranged from Nursing or Midwifery Officers to Chief Nursing Officers or Assistant Director of Nursing Services.

Measures

Demographic information was obtained from the participants through a form that requested the nurses' age in years (interval data); gender (nominal data) was coded as male $=0$, female $=1$; job rank (interval data was coded as nursing/midwifery officers $=1$, senior nursing/midwifery officers $=2$, principal nursing/midwifery officers $=3$, chief nursing officers $=4$, assistant directors of nursing $=$ 5 and job tenure in years (ordinal data) was coded as two to five years $=1$, six to ten years $=2,11-20$ years $=3,21-25$ years and above $=5$. The nurses gave the actual number of years they have spent in their present jobs.

Organizational commitment was assessed by the Organizational Commitment Questionnaire (OCQ) by Mowday et al (1979): OCQ describes the individual's identification with and involvement with the particular organization. It is a 15-item scale constructed on a 5-point Likert Scale that ranged from 1 = Strongly disagree to 5 = Strongly agree. Higher scores indicated higher levels of organizational commitment. Cronbach's Alpha coefficient of 0.85 was found for $O C Q$ in this study.

Job satisfaction was measured by means of the modified version of Job Satisfaction Scale (JSS) by Bayfield and Rothe (1951) as used by Judge, Locke, Durham and Kluger (1998). It is an 18-item scale constructed on a 5-point Likert scale ranging from 1 = Strongly Disagree to 5-Strongly Agree. Higher scores represent higher job satisfaction. The Cronbach's alpha coefficient of this scale was found to be 0.87 in this study.

Job involvement was measured by means of Job Involvement Scale (JIS) by Lodahl and Kejner (1965). Six items were selected from the 20-item Job Involvement scale JIS by Lodahl and Kejner (1965) for this study. The six items used in this study were the same as the Lodahl and Kejner's (1965) Six-item scale. The Six-item scale was used to measure job involvement in order to keep the overall instrument as concise as possible JIS was constructed on a 5-point Likert Scale ranging from $1=$ Strongly disagree to 5 = Strongly agree. Higher scores reflected higher job involvement. The Cronbach's alpha coefficient of JIS was found to be 0.82 in this study. 
Level of mentoring experience assessed as the extent to which the protégés believed or perceived the mentors provided career development and psychosocial functions to them was measured by means of a modified version of the 15-item Mentoring Scale (MS) by Scandura and Viator (1994). The MS was constructed on a 5-point Likert scale ranging from 1 = Strongly disagree to $5=$ Strongly agree, higher scores representing higher level of mentoring experience. The Cronbach's alpha coefficient of 0.93 was obtained for the mentoring scale. Adequate validity has been reported for this widely used measure by Scandura and Viator (1994) who carried out a factor analysis on the mentoring scale employing a varimax orthogonal rotation and identified three mentoring functions: career development, social support and role modeling. The present author also carried out a factor analysis on the Viator (1994) and identified the same three mentoring functions. I used the mentoring scale as a unidimensional scale that gave a single score because Scandura and Viator (1994) wrote that it could be used as a unidimensional scale. Also, I used the scale to obtain a single score for the analysis in this study.

A protégé's satisfaction with mentoring experience was measured by a four-item scale labeled satisfaction with mentoring experience adapted from "satisfaction with Mentoring Scale" by Ragins, Cotton and Miller (2000). The scale used a fivepoint Likert response format ( 1 =strongly disagree to $5=$ Strongly agree). Higher values represent greater satisfaction with the mentoring experience. The Cronbach's alpha coefficient for the scale was 0.83 (Ragins et al., 2000). For this study, the Cronbach's alpha coefficient for the scale was 0.82 .

Social support was measured using a modified version of multidimensional scale of perceived social support developed by Zimet, Dahlem, Zimet and Farley (1988). It measured the degree to which the respondents felt satisfied with available social support and sources of their support. It is a 12-item Likert-type scale which is scored on a 5 -point scale ranging from 1 (strongly disagree) to 5 (strongly agree). The items on the scale are loaded into factor groups relating to the sources of the social support namely family (Fam), friends (Fri), or significant others (So) (co-workers, professional association members and supervisors). High scores indicate high level of satisfaction with social support while low scores indicate low level of satisfactory social support. For this study, the Cronbach's alpha coefficient for this scale was 0.74 .

According to Zimet et al. (1988), the social support scale could be used as both multidimensional as well as unidimensional scale. In this study, the social support scale was used as a unidimensional scale to give a total picture of the available 
social support the respondents felt satisfied with. The three sources of social support are relevant to the economic and socio-cultural situations in Nigeria where there is collectivism and workers have to seek social support from family members, friends and significant others in matters of personal, social and career concerns.

Control variables

I controlled for some variables that have been theoretically and empirically linked to mentoring and job attitudes by previous researchers. These were age, job rank, years of experience on the job in the organization, and gender (Dreher \& Cox, 1996; Ragins, Cotton \& Miller, 2000).

Procedure

The present author and six research assistants with the help of some hospital personnel administered the four questionnaires to the participants after obtaining the consents of the nurses and the hospital authorities involved in this study. The hospital personnel assisted in the administration of the questionnaires in the wards of the hospitals involved in this study. The participants were told that the researcher had come to collect information on how the productivity and work attitudes of the nurses could be improved. They were assured that the information collected will be treated with confidentiality

\section{Data Analysis}

This study employed hierarchical multiple regression techniques in analyzing the data obtained. Data were checked for missing data and outliers and none were found. Neither was there heteroscedasticity. Before the hierarchical multiple regression analyses were conducted with the use of SPSS version 10, the data were centered to minimize multicollinearity by subtracting the sample mean for the major variable scales from each individual's score for the scales. To plot the significant interaction terms, regression lines between work attitudes (job involvement, job satisfaction and organizational commitment) as criterion and mentoring and satisfaction with mentoring as predictors were drawn at the high and low levels of mentoring and satisfaction with mentoring. Using the procedure recommended by Aiken and West (1991), the high and low subgroups were formed by using scores that fell one standard deviation above or below the mean of mentoring and satisfaction with mentoring respectively. 


\section{Results}

Table 1 presents the descriptive statistics of all the variables in the study and the correlation matrix.

Table 1: Means, standard deviations and Interco relation matrix of all variables in the study

\begin{tabular}{|c|c|c|c|c|c|c|c|c|c|c|c|}
\hline & Variables & 1 & 2 & 3 & 4 & 5 & 6 & 7 & 8 & 9 & 10 \\
\hline 1. & $\begin{array}{l}\text { Level of } \\
\text { Mentoring }\end{array}$ & 1.00 & & & & & & & & & \\
\hline 2 & $\begin{array}{l}\text { Satisfaction with } \\
\text { mentoring }\end{array}$ & .18 & 1.00 & & & & & & & & \\
\hline 3 & Social support & 17 & $.21^{*}$ & 1.00 & & & & & & & \\
\hline 4. & $\begin{array}{l}\text { Organizational } \\
\text { commitment }\end{array}$ & $.30^{*}$ & $.23 *$ & .15 & 1.00 & & & & & & \\
\hline 5. & Job involvement & $.25^{*}$ & $.21^{*}$ & $.22^{*}$ & $.20^{*}$ & 1.00 & & & & & \\
\hline 6. & Job satisfaction & $.20^{*}$ & $.27 *$ & $.19 *$ & .17 & $.23^{*}$ & 1.00 & & & & \\
\hline 7. & Gender & .13 & .15 & .09 & 11 & .12 & .15 & 1.00 & & & \\
\hline 8. & Age & .18 & 17 & .10 & .14 & .15 & .07 & .09 & 1.00 & & \\
\hline 9. & Job experience & $.19 *$ & .13 & .07 & .16 & .09 & .12 & .15 & $.23^{*}$ & 1.00 & \\
\hline \multirow[t]{3}{*}{10.} & Job status & .18 & .12 & .17 & $.21^{*}$ & .10 & .16 & .12 & $.20 *$ & $.20 *$ & 1.00 \\
\hline & Mean & 4.15 & 3.82 & 3.19 & 4.23 & 4.58 & 4.41 & - & 36.56 & 7.80 & 1.70 \\
\hline & S.D. & 6.30 & 1.80 & 2.50 & 5.20 & 3.50 & 6.30 & - & 7.80 & 4.70 & 2.20 \\
\hline
\end{tabular}

Table 2: Hierarchical multiple regression analysis of the prediction of job involvement from mentoring, satisfaction with mentoring and social support

\begin{tabular}{|c|c|c|c|c|c|c|c|}
\hline Variable entered & $\mathrm{R}^{2}$ & $\Delta R^{2}$ & $\mathrm{~F}$ & $\Delta \mathrm{F}$ & Df & Beta & T \\
\hline Step 1 & 0.06 & & 1.55 & 1.35 & 1,465 & & \\
\hline Gender & & & & & & 0.07 & 0.70 \\
\hline Age & & & & & & 0.13 & 1.50 \\
\hline Job experience & & & & & & 0.05 & 0.63 \\
\hline Job status & & & & & & 0.12 & 1.40 \\
\hline Step 2 & 0.24 & 0.18 & $6.30^{*}$ & $5.80 *$ & 1,463 & & \\
\hline Mentoring & & & & & & $0.32 *$ & $3.40^{*}$ \\
\hline Step 3 & 0.38 & 0.14 & $8.56^{*}$ & $6.70^{*}$ & 1,462 & & \\
\hline $\begin{array}{l}\text { Satisfaction with } \\
\text { mentoring }\end{array}$ & & & & & & $0.42^{*}$ & $4.70^{*}$ \\
\hline Step 4 & 0.47 & 0.09 & 9.43* & $5.00^{*}$ & 1,461 & & \\
\hline Social support & & & & & & $0.25^{*}$ & $4.20^{*}$ \\
\hline $\begin{array}{l}\text { Step } 5 \\
\text { Interaction terms }\end{array}$ & 0.58 & 0.11 & $7.60^{*}$ & $5.30^{*}$ & 4,457 & & \\
\hline Mentoring X SS & & & & & & $.23^{*}$ & $3.40^{*}$ \\
\hline $\begin{array}{l}\text { Satisfaction with } \\
\text { mentoring X SS }\end{array}$ & & & & & & $.21 *$ & $2.55^{*}$ \\
\hline Mentoring $X$ gender & & & & & & .06 & 1.60 \\
\hline $\begin{array}{l}\text { Satisfaction with } \\
\text { mentoring } X \text { gender }\end{array}$ & & & & & & .05 & 1.40 \\
\hline
\end{tabular}

Note: $\mathrm{N}=470, \mathrm{SS}=$ social support, ${ }^{*}=\mathrm{P}<0.05$ (2-tailed tests). 
The mean level of mentoring received by the nurses was 4.16 (S.D=6.30) and was above average of 3.0 (the minimum was 1.0, maximum was 5.0). The participants received most of the mentoring from friends, relations, former colleges and supervisors in their present work place. The mean value for satisfaction with mentoring was 3.82 (S.D=1.80) which was above average of 3.0 (minimum was 1.0, maximum was 5.0).

Results on Table 1 revealed that there were linear correlations between level of mentoring and each of the work attitudes - job involvement ( $r=.25, p<0.05)$, job satisfaction ( $r=.20, p<0.05)$, and organizational commitment $(r=.30, p<0.05)$. Similarly, satisfaction with mentoring experience was linearly correlated with organizational commitment $(r=.23, p<.05)$, job involvement $(r=.21, p<.05)$, and job satisfaction $(r=.27, p<.05)$. Social support also had linear correlations with job involvement $(r=.22, p<.05)$ and job satisfaction $(r=.19, p<.05)$ but not with organizational commitment. While job status had linear correlation with organisational commitment $(r=.21, p<.05)$, gender had very low correlations with any of the work attitudes.

Table 2 presents the results of hierarchical regressions for the prediction of job involvement from mentoring, satisfaction with mentoring and social support. As hypothesized in $\mathrm{H}_{1}$, gender did not predict work attitudes (see tables 2,3 , and 4 ) in step 1.

Table 3: Hierarchical multiple regression analysis of the prediction of job satisfaction from mentoring, satisfaction with mentoring and social support

\begin{tabular}{|c|c|c|c|c|c|c|c|}
\hline Variable entered & $\mathrm{R}^{2}$ & $\Delta R^{2}$ & $\mathrm{~F}$ & $\Delta \mathrm{F}$ & Df & Beta & $\mathrm{T}$ \\
\hline Step 1 & 0.07 & & 1.80 & 1.20 & 4,465 & & \\
\hline Gender & & & & & & 0.02 & 0.06 \\
\hline Age & & & & & & 0.09 & 0.52 \\
\hline Job experience & & & & & & 0.08 & 0.73 \\
\hline Job status & & & & & & 0.12 & 1.67 \\
\hline Step 2 & 0.27 & 0.20 & $9.80^{*}$ & $7.30^{*}$ & 1,463 & & \\
\hline Mentoring & & & & & & $0.34^{*}$ & $3.80^{*}$ \\
\hline Step 3 & 0.34 & 0.07 & $12.48^{*}$ & $7.80^{*}$ & 1,462 & & \\
\hline $\begin{array}{l}\text { Satisfaction with } \\
\text { mentoring }\end{array}$ & & & & & & $0.48^{*}$ & $5.60^{*}$ \\
\hline Step 4 & 0.42 & 0.08 & $10.52^{*}$ & $4.40^{*}$ & 1,461 & & \\
\hline $\begin{array}{l}\text { Social support } \\
\text { Step } 5 \\
\text { Interaction terms }\end{array}$ & 0.52 & 0.10 & $8.36^{*}$ & $4.30^{*}$ & 4,457 & $0.28^{*}$ & $3.70^{*}$ \\
\hline Mentoring X SS & & & & & & $0.20 *$ & $2.80^{*}$ \\
\hline
\end{tabular}


Satisfaction with

mentoring X SS

Mentoring $X$ gender

Satisfaction with

mentoring $X$ gender

Note: $\mathrm{N}=470, \mathrm{SS}=$ social support, ${ }^{*}=\mathrm{P}<0.05$ (2-tailed tests).
$.22^{*}$

$3.14^{*}$

.08

.03
1.10

0.07

Table 4: Hierarchical multiple regression analysis of the prediction of organisational commitment from mentoring, satisfaction with mentoring and social support

\begin{tabular}{|c|c|c|c|c|c|c|c|}
\hline Variable entered & $R^{2}$ & $\Delta R^{2}$ & $\mathrm{~F}$ & $\Delta \mathrm{F}$ & Df & Beta & $\mathrm{T}$ \\
\hline Step 1 & 0.08 & & 1.60 & 1.43 & 4,465 & & \\
\hline Gender & & & & & & 0.05 & 0.45 \\
\hline Age & & & & & & 0.07 & 0.56 \\
\hline Job experience & & & & & & 0.06 & 1.10 \\
\hline Job status & & & & & & 0.13 & 1.45 \\
\hline Step 2 & 0.30 & 0.22 & $10.50^{*}$ & $9.70^{*}$ & 1,463 & & \\
\hline Mentoring & & & & & & $0.54^{*}$ & $6.02^{*}$ \\
\hline Step 3 & 0.28 & 0.06 & $9.40 *$ & $6.43^{*}$ & 1,462 & & \\
\hline $\begin{array}{l}\text { Satisfaction with } \\
\text { mentoring }\end{array}$ & & & & & & $0.33^{*}$ & $4.85^{*}$ \\
\hline Step 4 & 0.30 & 0.02 & $2.10^{*}$ & 1.30 & 1,461 & & \\
\hline Social support & & & & & & 0.14 & 1.30 \\
\hline $\begin{array}{l}\text { Step } 5 \\
\text { Interaction terms }\end{array}$ & 0.40 & 0.10 & $6.40^{*}$ & $3.82^{*}$ & 4,457 & & \\
\hline Mentoring X SS & & & & & & $.25^{*}$ & $2.70^{*}$ \\
\hline $\begin{array}{l}\text { Satisfaction with } \\
\text { mentoring X SS }\end{array}$ & & & & & & $.30^{*}$ & $3.45^{*}$ \\
\hline Mentoring $X$ gender & & & & & & .05 & 0.06 \\
\hline $\begin{array}{l}\text { Satisfaction with } \\
\text { mentoring } X \text { gender }\end{array}$ & & & & & & .06 & 0.03 \\
\hline
\end{tabular}

Note: $\mathrm{N}=470, \mathrm{SS}=$ social support, ${ }^{*}=\mathrm{P}<0.05$ (2-tailed tests).

On tables 2, 3, and 4, addition of mentoring in step 2 of the regressions, as hypothesized in $\mathrm{H} 2$ made separate contributions to the prediction of job involvement $(\Delta R 2=0.18$, Beta $=0.32, P<.05)$, job satisfaction $(\Delta R 2=0.20$, Beta $=0.34, P<.05)$ and organisational commitment $(\Delta R 2=0.22$, Beta $=0.54, P<.05)$ among the nurses. When satisfaction with mentoring was entered in step 3 , as proposed in $\mathrm{H}_{3}$, it similarly predicted job involvement, job satisfaction and organisational commitment of the nurses. Addition of social support in step 4 in tables 2,3 , and 4 , as hypothesized in $\mathrm{H}_{4}$, made separate contribution to the prediction of job involvement $\left(\Delta R^{2}=0.09\right.$, Beta $=$ 0.25, $\mathrm{p}<.05)$ and job satisfaction $\left(\Delta R^{2}=0.08\right.$, Beta $\left.=0.28, p<.05\right)$ but not organisational commitment. In summary, the results showed that, for the most part, the independent variables were linear predictors and are mildly associated with work attitudes among the nurses.

The moderating effects of social support and gender, as hypothesized in $\mathrm{H}_{5}$ and $\mathrm{H}_{6}$ were tested in step 5 . In step 5 of tables 2, 3, and 4, addition of the cross-product interaction terms to the regression equation, (mentoring $X$ social support, satisfaction 
with mentoring $X$ social support, mentoring $X$ gender, and satisfaction with mentoring $X$ gender) made substantial contributions to the prediction of job involvement, job satisfaction and organisational commitment. When beta values were examined, mentoring $X$ social support made substantial contribution to the prediction of job involvement (Beta $=0.23, P<.05)$, job satisfaction (Beta $=0.20, P<.05)$, and organisational commitment (Beta $=0.25, \mathrm{p}<.05$ ). Similarly, satisfaction with mentoring $X$ social support substantially contributed to the prediction of job involvement (Beta $=0.21, \mathrm{p}<.05$ ), job satisfaction (Beta $=0.22, \mathrm{p}<.05$ ), and organisational commitment $($ Beta $=0.30, p<.05)$. However, mentoring $X$ gender and satisfaction with mentoring $X$ gender interactions did not make any meaningful contribution to the prediction of work attitudes.

The plots of the interactions: mentoring $X$ social support, and satisfaction with mentoring $X$ social support are presented in figures $1 A \& B, 2 A \& B$ and $3 A \& B$. These indicate that the relationship between mentoring and work attitudes on the one hand and between satisfaction with mentoring and work attitude on the other hand are stronger among nurses who have higher social support than those with lower social support.

Figure 1: Plots of interactions between mentoring and social support (SS) and between satisfaction with mentoring and social support (SS) on nurses' job involvement (JI).
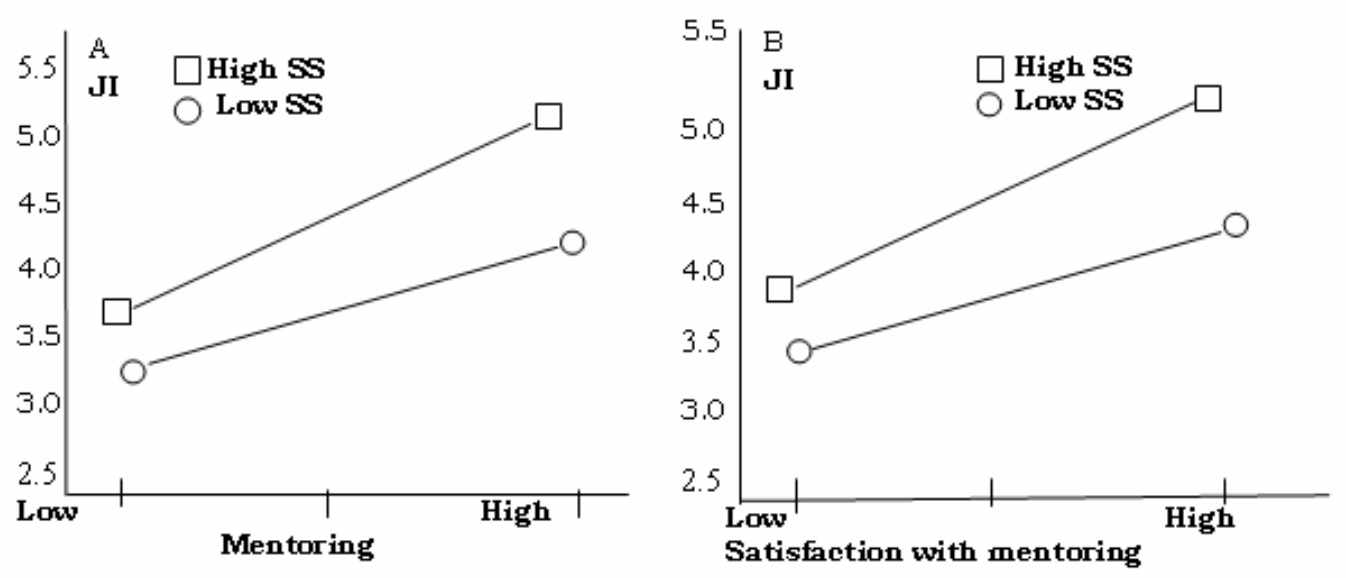
Figure 2: Plots of interactions between mentoring and social support (SS) and between satisfaction with mentoring and social support (SS) on nurses' job satisfaction (JS)
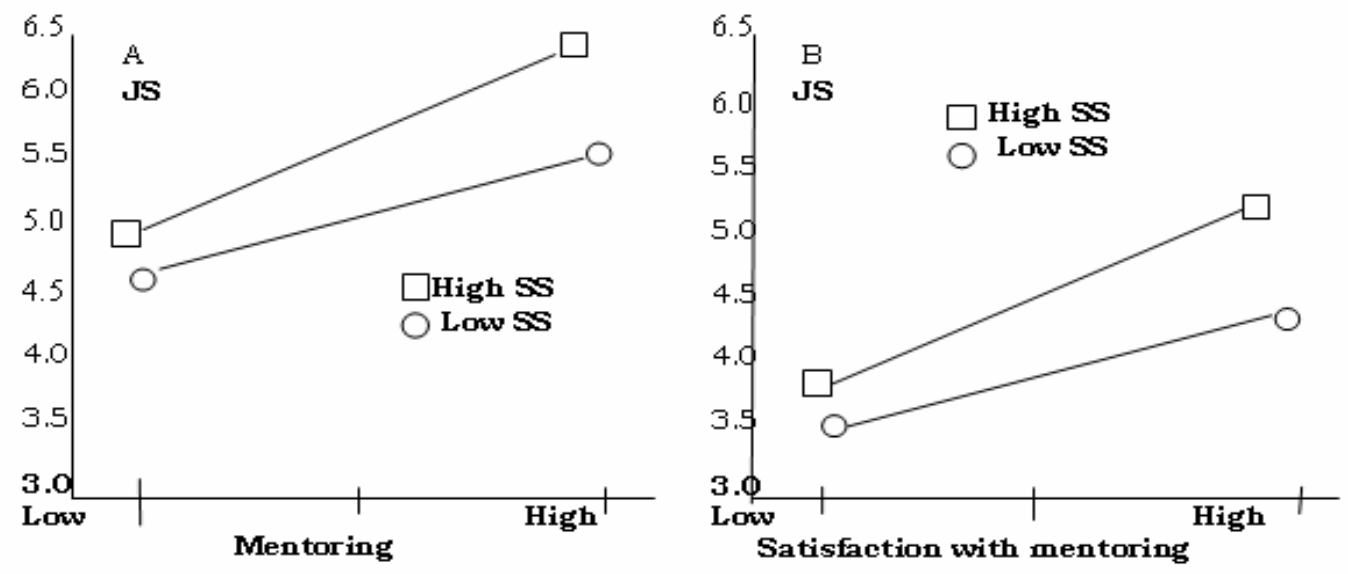

Figure 3: Plots of interactions between mentoring and social support (SS) and between satisfaction with mentoring and social support (SS) on nurses' organizational commitment (OC)
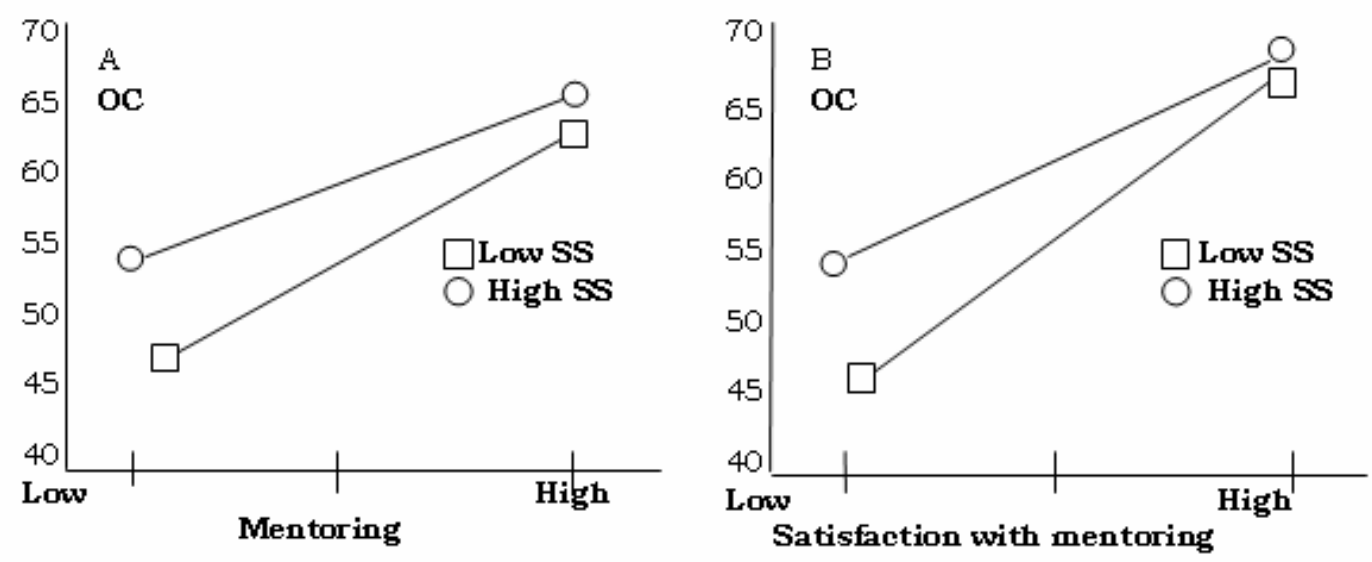

\section{Discussion}

This study examined the extent to which the independent variables (gender, level of mentoring, satisfaction with mentoring and social support) jointly and individually predict work attitudes among the nurses. Also the study investigated the extent to which social support and gender moderate the relationship between level of mentoring, satisfaction with mentoring and work attitude of the nurses.

The results of this study revealed that all the independent variables-except gender, predicted work attitudes of the nurses. Gender failed to predict the work attitudes 
(job involvement, job satisfaction and organisational commitment). These results contradict the findings of Carmeli (2003) who found significant relationships between gender and work attitudes. However, these results were in line with the work of Ragins et al. (2000) who found no significant relationship between gender and work attitudes.

Mentoring and satisfaction with mentoring separately predicted all the work attitudes (job involvement, job satisfaction and organisational commitment) of the nurses as it has in many previous studies (Bedini, 2003; Caine, 2008; Chansrichauwla, 2006; Koberg et al., 1998; Lankau and Scandura, 2002; Ragins et al., 2000; Scandura \& Williams, 2004; Wasserstein et al., 2007). Mentoring and satisfaction with mentoring were positively related to job and career attitudes.

These results demonstrated that the level of mentoring relationships and satisfaction with mentoring provided opportunities for the mentored nurses to acquire and display job-related knowledge, skills and abilities resulting in more job involvement, job satisfaction and organisational commitment. That social support predicted job involvement and job satisfaction but not organisational commitment support the findings of previous researchers (Allen \& Finkelstein, 2003; Higgins \& Thomas, 2001; Kram, 1985) who found that social support predicted job and career outcomes. Social support did not predict organisational commitment thus contradicting the work of the cited authors. That social support predicted job involvement and job satisfaction was because it served as a protective factor or buffer against responses to stressors arising from work. For instance, social support may compensate for loss of social relationships at work and heavy workload.

Social support moderated the relationships between mentoring and work attitudes on the one hand and between satisfaction with mentoring and work attitudes on the other. These results supported the work of previous researchers who argued that effective use of social support paves the way for effective mentoring relationship (Allen \& Finkelstein, 2003; Higgins and Thomas, 2001; Siebert et al., 2001; van Emmerik, $2004,2008)$. These authors were of the view that mentoring combined with other supportive relationships were associated with better work outcomes. van Emmerik (2008) argued that mentoring flourishes under favourable team or multiple support conditions. These results can be attributed to the fact that the nurses perceived that with the level of mentoring they had, the degree of satisfaction they had with mentoring and the stressful situation in which they work, they felt that they needed more social support from individuals in or outside the work organization in order to improve their work attitudes. 
Another explanation for the findings from this study can be based on some sociocultural factors. For example, the Nigerian society is more collectivistic than individualistic and as such, the workers are likely to seek more social support from family and friends on issues of personal, social and career importance (Salami 1998; 2008b). Also because the Nigerian society is cautious about disclosing personal and social information to people outside the family it is appropriate for the workers to seek social support from family and friends on matters of personal, social and even career concerns (Salami, 1998).

They may also seek support from significant others such as co-workers, professional association members, and supervisors on matters dealing with career development. Also the fact that there are financial constraints, high unemployment and jobs are difficult to get, might have influence on employers and workers' behaviours and attitudes towards mentoring. Those who are employed will want to remain on their jobs and as such they will seek social support from family members, friends and significant others when it comes to personal, social and career problems. The social support from these multiple sources is likely to have influenced positively the mentoring relationships the workers had which in turn might have influenced their work attitudes positively.

Finally, the results of the present study showed that gender did not moderate the relationship between mentoring and work attitudes as well as between satisfaction with mentoring and work attitudes. These results corroborate the findings of Ragins et al. (2000), but contradicted that of Scandura and Williams (2001), Chandler \& Kram (2010), Fowler et al. (2007) and Kamler \& Rasheed (2006). These results are because no matter the gender of the nurses, they all benefited from mentoring and had some satisfaction with the mentoring relationships and these invariably substantially influenced their work attitudes. These findings are surprising in view of some sociocultural factors such as emphasis on masculinity, cross-gender mentoring difficulties, gender-role stereotyping, occupational stereotyping, individual and organizational factors that inhibit prospering of mentoring relationship for the women. It is very likely that the multiple sources of social support might have influenced the nurses' mentoring positively regardless of their gender which in turn, influenced their work attitudes positively.

Implications of the Findings

The results of this study demonstrated that some work attitudes (job involvement, job satisfaction and organizational commitment) were predicted by the level of mentoring, satisfaction with mentoring and social support indicated by the nurses. A 
nurse with higher level of mentoring and higher satisfaction with mentoring and social support developed higher job involvement, job satisfaction and organizational commitment. The implication of these findings is that formal or informal mentoring should be encouraged among the nurses and that mentoring programmes that would facilitate satisfaction with mentoring should be designed. Work organization managements should be enlightened about the benefits to be derived from mentoring programmes by both individuals and organizations. Therefore, mentoring programmes should be developed by counselling and personnel psychologists for work organizations including hospitals, clinics and other health-care establishments.

The results from this study revealed that social support moderated the relationship between mentoring and work attitudes on the one hand and satisfaction with mentoring experience and work attitudes on the other. The implication of these findings is that, based on the economic constraints, high unemployment, sociocultural factors- collectivism, occupational stereotyping, emphasis on masculinity and the tendency for the Nigerian society to frown at certain relationships (crossgender mentoring) which might inhibit mentoring relationships, social support from family members, friends and co-workers could complement whatever may be the levels of mentoring and satisfaction with mentoring experience had by the nurses in order to develop more positive work attitudes. Some employees may not be aware that their career or psychosocial development needs can be satisfied by means other than traditional mentoring. The results of the present study can be used by career counselling practitioners to help demonstrate the viability of connecting with an array of individuals, both in and outside the organizational setting, to improve positively the mentoring relationship and work attitudes and outcomes of the nurses.

Because current financial constraints, unemployment and other socio- cultural factors in Nigeria, pose challenges to the viability of using one-on- one mentoring models to assist workers, it is suggested that a system of group mentoring (team or multiple mentoring) combined with social support from family, friends and significant others is put in place to help nurses and other workers to gain confidence, competence, positive work attitudes and improved job performance.

Limitations and future studies

A limitation of this study is worth noting. This study is cross-sectional in nature and as such one can not disentangle cause-and-effect relationship. Future researchers could conduct longitudinal studies in order to be able to make cause-and-effect conclusion. Another limitation is social desirability effect. It is worth mentoring that it is possible that a social desirability effect/response bias could be present in the results 
of this study. This could arise from some socio-cultural practices in which the Nigerian society does not always look favourably on certain relationships. This could have influenced the responses given in the questionnaires. Future research could consider investigating the impact of social desirability on participants' responses on other selfreport measures.

Despite this limitation, this study had demonstrated the relationships of mentoring and satisfaction with mentoring with work attitudes of nurses in Nigeria and the moderating role of social support on the relationships. The contribution of this study is that it has been able to conduct a cross-cultural replication of western findings in a developing country. It has also shown that there is need to combine social support from multiple sources such as family, friends, co-workers and supervisors with mentoring because of some economic and socio-cultural factors that may inhibit effective mentoring relationship.

\section{References}

Adeyemo, D.A. (2006). The usefulness of some selected psychological variables in predicting career commitment among nurses in Oyo State, Nigeria. The African Symposium: An On Line Journal of African Educational Research Network, June 2006, 8289.

Aiken,L.S.\& West,S.G.(1991) Multiple regression: Testing and interpreting interactions. Newbury Park, CA: Sage.

Allen, T.D. \& Finkenkelstein, L,M. (2003). Beyond mentoring: Alternative sources and functions of developmental support. Career Development Quarterly, 51 (4), 346-355.

Allen, T.D.; Eby,L.T.;Poteet, M.L.,Lentz,E.\& Lima, L. 2004). Career benefits associated with mentoring for protégés: A meta-analysis. Journal of Applied Psychology, 89(1), 127-136.

Bedini, L.A. (2003). Benefits of mentoring for practitioners in therapeutic Recreation, The Therapeutic Recreation Journal, Third Quarter, 1-2.

Brayfield, A.H. \& Rothe, H.F. (1951). An index of job satisfaction. Journal of Applied Psychology, 35, 307-311. 
Caine, R.M. (2008). A comparative evaluative survey of mentoring and job satisfaction. Perceptions of clinical nurse specialist (DISS). Retrieved 14 February 2008 from www.nursinglibrary.org/portal/main/aspx? pageid $=4024 \&$ sid $=668$

Carmeli, A. (2003). The relationship between emotional intelligence and work attitudes, behaviour and outcomes. An examination of senior managers. Journal of Managerial Psychology, 18(8), 788-813.

Chansrichawla, S. (2005). Leadership-supported mentoring: The key to enhancing organisational commitment and retaining newcomers. Sasin Journal of Management, 11(1), retrieved 11 February 2008 from www.sasin.edu/research/journal/11-1

Chao, G.T., Walz, P.M. \& Gardner, P.D. (1992). Formal and informal mentorship: A comparison on mentoring functions and contrast with non-mentored counterparts. Personnel Psychology, 45: 619-636.

Chandler, D.E \& Kram, K.E. (2010). Mentoring and developmental networks in the new career Context. Retrieved January 12, 2010 from http:// www. Management. bu.edu/academic/ research/kram. pdf.

Chang,E.M.,Hancock, K.M.,Johnson, A., Daly, J. Jackson, D. (2005). Role stress in nurses: Review of related factors and strategies for moving forward. Nursing \& Health Sciences, 7, 57-65.

Dreher, G.F. \& Cox, T.H. (1996). Race, gender, and opportunity: A study of compensation attainment and the establishment of mentoring relationships. Journal of Applied Psychology, 81, 297-308.

Eby, L.T., McManus, S.E., Simon, S.A. \& Russell, J.E.A (2000). The protégés perspectives regarding mentoring experiences: The development of taxonomy. Journal of Vocational Behaviour, 57, 1-21.

Ecklind, M. (1998). The relationship of mentoring to job satisfaction of critical care nurses. Journal of New York State Nurses Association, 29(2), 13-15

Fowler, J.L.; Gudmundsson, A.J. \& O'Gorman, J.G. (2007). The relationship between mentee-mentor gender combination and the provision of distinct mentoring functions. Women in Management Review, 22(8), 666-681.

Galbraith, M.W. (2001). Mentoring development for community college faculty. Retrieved 12th September 2006 from www.schoolcraft.edu/pdfs/cce/Galbraith.pdf. 
Greene, M.T. \& Puetzer, M. (2002). The value of mentoring: A strategic approach to retention and recruitment. Journal of Nursing Care Quality, 17 (1), 63-70.

Hegstad, C.D. (1999). Formal mentoring as a strategy for human resource development: A review of research. Human Resource Development Quarterly, 10, 383-390.

Higgins, M.C. \& Thomas, D.A (2001).Constellations and careers: Towards understanding the effects of multiple development relationships. Journal of Organizational Behaviour, 22,223-247.

Judge, T.A.; Locke, E.A., Durham, C.C. \& Kluger, A.N. (1998). Dispositional effects on Job and life satisfaction: The role of core evaluations. Journal of Applied Psychology, 83(1), 17-34.

Kamler, E. \& Rasheed, S. (2006). Mentoring academic women: struggle for advancement and Strategies for change. Research and Practice in Social Sciences. 2(1), 1-15.

Kilcher, A. \& Sketris, I. (2003). Mentoring resource book: A guide for faculty, researchers and decision-makers. Halifax.

Koberg, C.S., Boss, R.W. \& Goodman, E. (1998). Factors and outcomes associated with mentoring among health-care professional. Journal of Vocational Behaviour 53(1), 58-72.

Kram, K.E. (1985). Mentoring at work: Developmental relationships in organizational life. Glenvier, IL: Scott, Foresman.

Kuyper- Rushing, L. (2001). A formal mentoring programme in a university library: Components of a successful experiment. Journal of Academic Librarian, 27(6), 440-446.

Lankau, M.J. \& Scandura, T.A. (2002). An investigation of personal learning in mentoring relationships: Contents, antecedents and consequences. Academy of Management Journal. 45(4), 779-790.

Lodahl, T.M. \& Kejner, M. (1965). The definition and measurement of job involvement. Journal of Applied Psychology. 49, 24-33.

Mowday, R.T.; Steers, R.M. \& Porters, L.W. (1979). The measurement of organizational commitment. Journal of Vocational Behaviour, 14, 224-247. 
National Bureau of Statistics, (2007). Annual Abstracts of Statistics, National Bureau of Statistics, Garki-Abuja.

Ragins, B.R., Cotton, J.L. \& Miller, J.S. (2000). Marginal mentoring: The effects of type of mentor, quality of relationship and programme design on work and career attitudes. Academy of Management Journal, 43(6), 1177-1194.

Salami, S.O. \& Olomitutu, M.A. (2002). Job satisfaction variables as correlates of career commitment among Nigerian nurses. Nigerian Journal of Social Work Education, 6, 20-31.

Salami, S.O. (1998). Attitudes towards counselling among rural college students in Nigeria. Ife PsychologIA: An International Journal, 6(2), 116-31.

Salami, S.O. (2002). A comparative analysis of the impact of job involvement on the work-leisure relationships among teachers and nurses. Ife Journal of Psychology, 4(1), 113.

Salami, S.O. (2008a). Psychosocial factors as predictors of mentoring among nurses in Southwestern Nigeria. Journal of Workplace Learning, 20 (5), 348-363.

Salami, S.O. (2007). Relatioship between work -family conflicts and work attitudes among secondary school teachers in Southwest Nigeria. European Journal of Scientific Research. 18(3), 551-550.

Salami, S.O. (2008b). Roles of personality, vocational interests, academic achievement and socio-cultural factors in educational aspiration of secondary school adolescents in southwestern Nigeria. Career Development International, 13(7), 630-647.

Seibert, S.E., Kraimer, M.L \& Liden, R.C.(2001). A social capital theory of career success. Academy of Management Journal, 44(2), 219-237.

Scandura, T.A. \& Viator, R. (1994). Mentoring in public accounting firms: An analysis of Mentor-protégé relationships, mentorship functions and protégé turnover intentions. Accounting, Organisations and Society, 19(8), 717-734.

Scandura, T.A. \& Williams, E.A. (2001). An investigation of the moderating effects of gender on the relationships between mentorship initiation and protégé perceptions of mentoring functions, Journal of Vocational Behaviour, 59, P343-365.

Scandura, T.A \&Williams, E.A. (2004). Mentoring and transformation leadership: The role of Supervisory career mentoring. Journal of Vocational Behaviour, 65,448-468. 
Tenenbaum, H.R., Crosby, F.J. \& Gliner, M.D. (2001). Mentoring relationship in graduate school. Journal of Vocational Behaviour, 59, 326-341.

Thomas, C.H. \& Lankau, M. J. (2009). Preventing burnout: The effects of LMX and mentoring on socialization, role stress and burnout. Human Resource Management, $48(3), 417-432$.

Van Emmerik, I.J.H.(2004). The more you can get the better: mentoring constellations and intrinsic career success. Career Development International, 9(6), 578-594.

Van Emmerik, I.J.H.(2008). It is not only mentoring: The combined influences of individuallevel and team -level support on job performance, Career Development International, 13(7), 575-593.

Van Emmerik, H.; Baugh, S.G. \& Euwema, M.C. (2005). Who wants to be a mentor? An examination of attitudinal, instrumental, and social motivational components. Career Development International, 10(4), 310-324.

Wasserstein, A.G., Quistberg, D.A. \& Shea, J.A. (2007). Mentoring at the University of Pennsylvania. Results of a faculty survey. Journal of General Internal Medicine, 22 (2), 210-214.

Zimet G.D., Dahlem, N.W., Zimet, S.G., \& Farley, G.K. (1988). The Multidimensional Scale of Perceived Social Support. Journal of Personality Assessment. 52(1), 30-41.

About the author:

Dr Samuel O.Salami received his Ph.D from the University of Ilorin, Ilorin Nigeria. He is a Senior Lecturer in Counselling Psychology at the Department of Guidance and Counseling, University of Ibadan, Ibadan, Nigeria but currently on Sabbatical leave in the Kampala International University, Kampala, Uganda. His research interests include mentoring, leadership, employee commitment, job attitudes, career development, organizational conflict resolution and occupational stress. His research has been published in the Europe's Journal of Psychology, European Journal of Scientific Research, Career Development International Journal, Journal of Workplace learning, Women in Management review and International Journal for the Advancement of Counselling.

E-mail address: drsosalami2002@yahoo.co.uk 